\title{
長尺鏡ボルトエの地山補強効果に関する 簡易評価モデルの提案
}

\author{
宮野前俊一 ${ }^{1} \cdot$ 森田篤 $^{2} \cdot$ 酒井照夫 $^{3} \cdot$ 松井幹雄 $^{4} \cdot$ 梨本裕 $^{5} \cdot$ 大久保誠介 $^{6}$ \\ 1 正会員 前田建設工業株式会社 土木本部 土木技術部（干179-8903 東京都練馬区高松 5-8 J.CITY） \\ E-mail:miyanomae.s@jcity.maeda.co.jp \\ 2 前田建設工業株式会社 土木本部 土木技術部（同上） \\ 3フェロー会員 前田建設工業株式会社 台湾高雄地下鉄工務所 \\ ${ }^{4}$ 正会員 前田建設工業株式会社 土木本部 土木技術部（干179-8903 東京都練馬区高松 5-8 J.CITY） \\ 5 前田建設工業株式会社 土木本部 土木技術部（同上） \\ ${ }^{6}$ 正会員 東京大学教授 工学系研究科地球システム工学専攻（†113-8656 東京都文京区本郷 7-3-1） \\ NATM によるトンネル施工では，切羽前方地山の安定を確保することがトンネルを安全かつ安定に施 \\ 工するために必要である。特に地山強度比が小さな押し出し性地山においては, 切羽前方地山を補強す \\ るための対策工として，長尺鏡ボルト工が広く採用されている. \\ 本論文では軸対称 FEM を用いて，長尺鏡ボルト工による効果を定量的に評価するための簡易モデルを \\ 提案し, 内空変位と地表面沈下の計算結果を計測結果と比較することでその実用性を明らかにする.
}

Key Words : NATM, tunnel, face bolting, axi-symmetric FEM, in-situ measurement

\section{1. はじめに}

NATM によるトンネル施工では, 切羽前方地山の 安定を確保することが不可欠である。特に地山強度 比が小さな押し出し性地山や小土被りの未固結地山 のように，切羽前方地山の安定確保が困難な場合に は，対策工が必要となる。近年ではガラス繊維補強 プラスチック管（以降，GFRP 管と称す）を鏡ボル ト（あるいは鏡止めボルト）と称し，これを 1 シフ トあたり長さ $10 〜 20 \mathrm{~m}$ 程度として切羽前方地山に 打設する長尺鏡ボルト工が，対策工として広く採用 されている ${ }^{1)}$.

これまで長尺鏡ボルト工による地山補強効果は経 験的には認められている ${ }^{2)}$ もの, その効果を定量 的に評価し，積極的に設計や施工に反映することは 少なかったと考えられる.これは 3 次元的なトンネ ル挙動がトンネル横断方向に着目して 2 次元的に評 価されるのが一般的であることや, 切羽前方地山の 挙動に着目した計測が行われることはほとんどなか ったためであると考えられる。

Lunardi $^{3}$ は実験や計測事実から切羽前方地山の安 定性がトンネルの安定性に密接に関わっていること に着目し, 切羽前方地山を積極的に補強することに より変形を抑制する ADECO-RS 工法を提案し, 実施 工においてその有効性を確認している. また数值解
析技術の発展に伴い，長尺鏡ボルト工の地山補強効 果に着目し, 内空変位や鏡ボルトのひずみ量などの 計測結果と 3 次元掘削解析結果とを比較した例が多

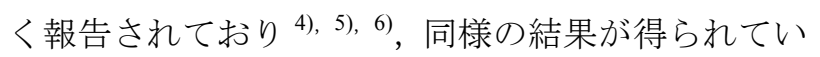
る.しかしながら設計段階で長尺鏡ボルト工にどの 程度の地山補強効果があるかを簡易に予測すること や, 施工中に得られる計測結果を解釈しながら対策 規模の妥当性を評価することは困難なものとなって いる.

そこで本論文では, まず地山強度比が小さな地山 を対象として, 切羽前方地山の安定性がトンネルの 安定性に与える影響について軸対称 FEM による検 討を行う。長尺鏡ボルト工にどのような地山補強効 果があるかについて検討した後, 軸対称 FEM を用 いて長尺鏡ボルト工の効果を定量的に評価するため の簡易モデルを提案し，現場計測結果と比較するこ とでその適用性について考察する.

\section{2. 切羽前方地山の安定性がトンネルの安定性 に与える影響}

\section{（1）検討方法}

トンネル周辺地山が平面ひずみ状態にあるとみな し, 掘削に伴うトンネル横断方向の応力変化や変形 


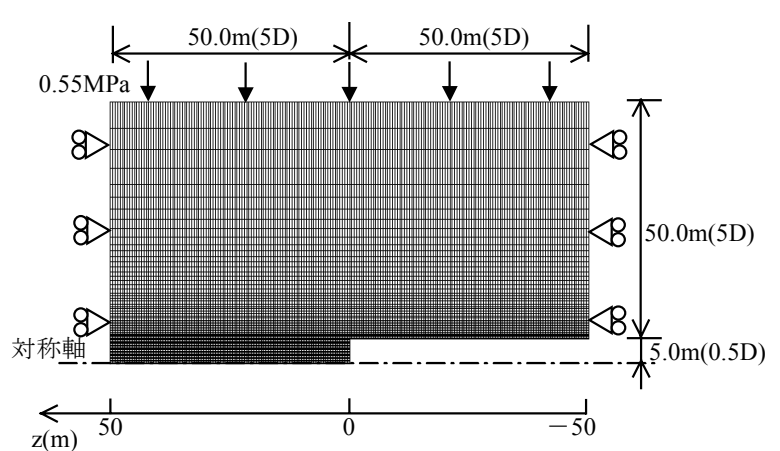

(a) 全体図

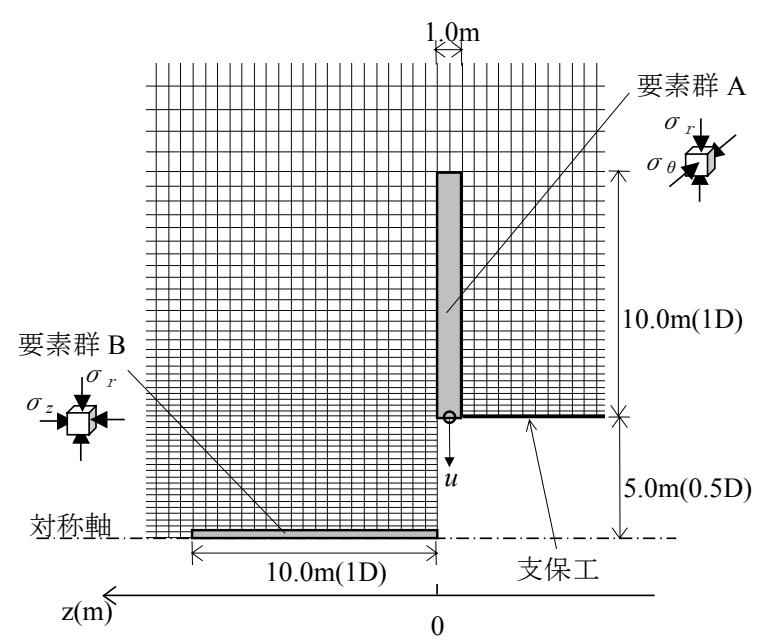

(b) 桩大図

図-1 解析モデル

量を得ることができる理論解はこれまでいくつか提 案され，広く用いられている。しかしながら切羽前 方地山の掘削に伴う応力変化や変形量について, 吹 付けコンクリートや鋼製支保工といった支保工の設 置を考慮しつつ，理論的に解釈した例は見当たらな い.それらの把握のため本論文では FEM を用いる こととする.

長尺鏡ボルト工を採用するようなトンネルにおい ては補助ベンチ付全断面工法やミニベンチカット工 法が採用されることが多く ${ }^{7)}$ ，インバート部への吹 付けやストラットの設置あるいは本設のインバート による断面閉合が早期に行われる.さらに力学的な 安定を得るためにインバートの曲率を大きくし，円 形に近い断面が採用されることが多い。このような 場合には軸対称モデルでトンネルの掘削過程を表現 できるものと考えた.

用いた解析モデルを図-1に示す. トンネルの掘削 幅 $D$ を $10.0 \mathrm{~m}$, 一掘進長を $1.0 \mathrm{~m}$ として, 切羽位置 $z$ が-50m ( $z=-5 D)$ から $50 \mathrm{~m}(z=5 D)$ まで逐次掘削解 析を行う。地山および支保工の条件は, 粘性土地山 に掘削されたトンネルのものを用いる，なお，本卜 ンネルで得られた計測結果については, 後に詳しく
表-1 粘性土地山に掘削されたトンネルの地山物性

\begin{tabular}{|l|c|}
\hline ヤング率 $E(\mathrm{MPa})$ & 10 \\
\hline ポアソン比 $\nu(-)$ & 0.4 \\
\hline 内部摩擦角 $\phi\left({ }^{\circ}\right)$ & 10 \\
\hline 粘着力 $C(\mathrm{MPa})$ & 0.08 \\
\hline 一軸圧縮強度 $\sigma_{c}(\mathrm{MPa})$ & 0.2 \\
\hline 引張強度 $\sigma_{t}(\mathrm{MPa})$ & 0.02 \\
\hline 単位体積重量 $\gamma\left(\mathrm{kN} / \mathrm{m}^{3}\right)$ & 22 \\
\hline
\end{tabular}

述べる. 地山は線形弾性体 (以降, 弾性体と称する) ないしは Mohr-Coulomb の破壊規準に従う弾完全塑 性体（以降, 弾塑性体と称寸る）とし, 三軸圧縮試 験や平板載荷試験より得られた表-1 の物性值を用 いる．本トンネルの土被りは $20 \mathrm{~m}$ ，スプリングライ ンから天端までの高さは $5 \mathrm{~m}$ であり，スプリングラ イン位置で計算される $0.55 \mathrm{MPa} の$ 初期応力を等方的 に各要素に与える. 支保工として厚さ $0.25 \mathrm{~m}$, ヤン グ率 $3.4 \mathrm{GPa}^{8)}$ ， ポアソン比 0.2 の吹付けコンクリー 卜およびヤング率 $210 \mathrm{GPa}$ の鋼製支保工（H-200, 設 置間隔 $1.0 \mathrm{~m}$ ) を合成部材としてシェル要素でモデル 化し, 掘削毎に手前 $1.0 \mathrm{~m}$ 部分に施工されるものと する，なおロックボルトは，本トンネルでは施工さ れていない，モデル境界は境界条件による影響を低 減させるため, ここでは $5 D$ とした.

\section{（2）トンネル周辺地山の応力，ひずみ状態}

切羽位置 $z$ が $50 \mathrm{~m}$ の時点 ( $5 D$ 通過時) での要素 群 $\mathrm{A}$ （図-1(b)）にお㇒るトンネル周方向応力 $\sigma_{\theta}$ お よびトンネル半径方向応力 $\sigma_{r}$ (それぞれ圧縮応力を 正とする）を図-2に，トンネル半径方向のひずみ $\varepsilon_{r}$ (引張ひずみを正とする）を図-3 に示す，それ ぞれの図において横軸はトンネル壁面からの距離で ある.地山が弾塑性体の場合には $\sigma_{\theta}$ がピークを示す 以浅の地山は塑性化している.

切羽位置 $z$ が $0 \mathrm{~m}$ の時点 (切羽到達時) での要素 群 $\mathrm{B}$ (図-1(b) ) におけるトンネル半径方向応力 $\sigma_{r}$ およびトンネル軸方向応力 $\sigma_{z}$ (それぞれ圧縮応力を 正とする）を図-4に，トンネル軸方向ひずみ $\varepsilon_{z}$ (引 張ひずみを正とする）を図-5に示す，それぞれの図 において横軸はトンネル切羽面からの距離である。 地山が弾塑性体の場合には $\sigma_{r}$ がピークを示寸以浅 の地山は塑性化している.

図-2 と図-4 を比較すると,トンネル横断方向の塑 性化領域の拡がりは, 切羽前方に比較し小さい. こ れは支保工の設置や掘削面の形状の違いによる効果 である. 図-4より, 切羽前方地山が塑性化する場合 にはトンネル半径方向応力 $\sigma_{r}$ が小さくなり, 切羽前 方地山から周辺地山に内圧として作用寸る応力が小 


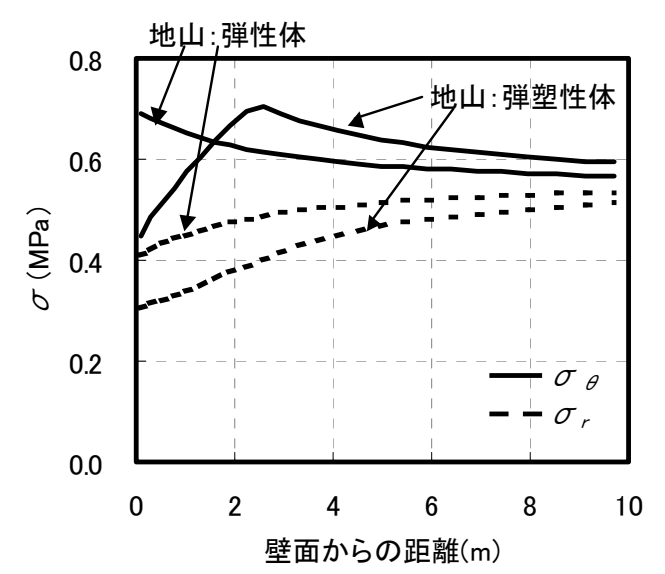

図-2 要素群 A のトンネル周方向および半径方向の応力 (5D 通過時)

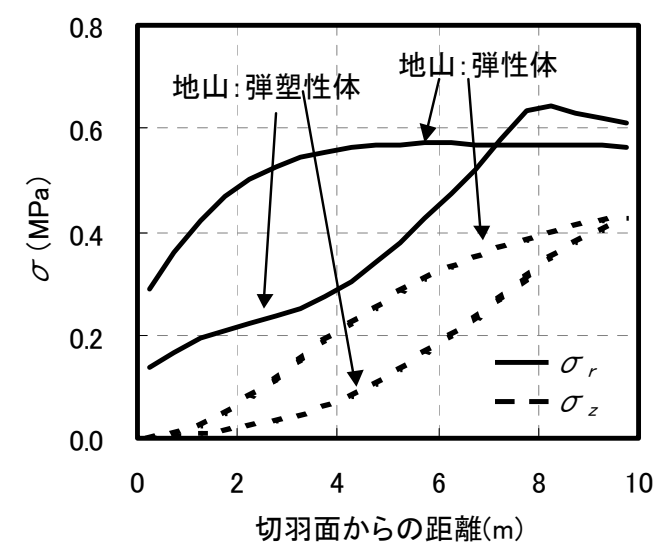

図-4 要素群 B のトンネル半径方向および軸方向の応力 (切羽到達時)

さくなることが分かる. 図-5より，切羽前方地山が 塑性化する場合にはトンネル軸方向ひずみ $\varepsilon_{z}$ が大 きくなり，切羽面からトンネル内空方向に向かう押 出し変位が大きくなる.

本解析で想定した一軸圧縮強度と初期応力から求 まる地山強度比は，0.36である。このように地山強 度比が小さな場合には, 切羽前方地山が塑性化し, 先行変位や押し出し変位が大きくなる.したがって, このような地山でトンネルを安全かつ安定に施工す るには，切羽前方地山に対策を施す必要がある.

切羽前方地山の変形状態について考察する. トン ネル横断方向について図-2 と図-3 を見てみると,卜 ンネル壁面に近いほどトンネル半径方向のひずみが 大きくなり，地山を弾塑性体とした場合には， $\sigma_{\theta}$ がピークを示すトンネル壁面から $2.5 \mathrm{~m}$ の位置を境 にトンネル半径方向のひずみが急激に大きくなる. それに対し,切羽前方地山について図-4 と図-5を見 てみると, トンネル軸方向のひずみは切羽面に近い ほど大きくはならず，切羽面からおよそ $2 \mathrm{~m}$ の位置

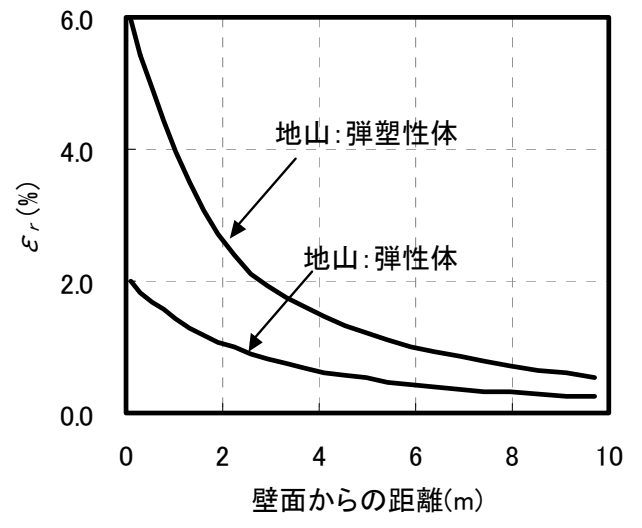

図-3 要素群 A のトンネル半径方向のひずみ ( $5 D$ 通過時)

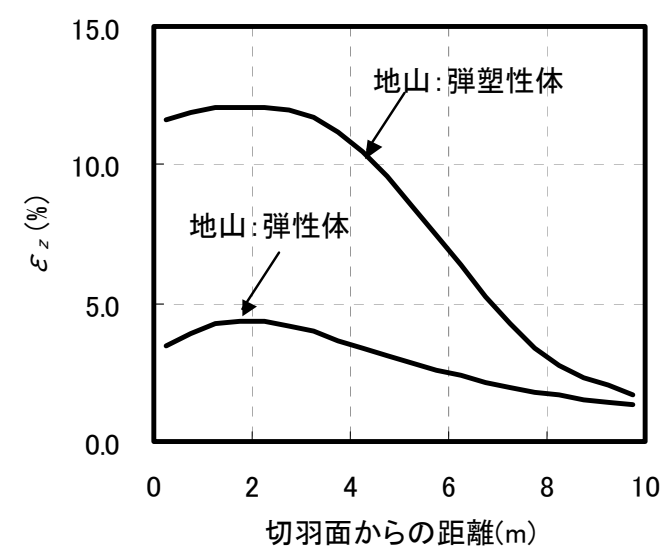

図-5 要素群 B のトンネル軸方向のひずみ (切羽到達時)

において最も大きくなる．また， $\varepsilon_{z}$ がピークを示す 位置と $\sigma_{r}$ がピークを示寸位置が異なる.この理由に ついて考察する. 北里ら ${ }^{9}$ は長尺鏡ボルトが地山と 一体となって挙動するものとして 3 次元弾塑性掘削 解析を行った．示されている長尺鏡ボルトの発生軸 力から考えれば，切羽前方地山のトンネル軸方向の ひずみは，ここで得られた解析結果と同様に，切羽 面ではなく切羽面以深で最も大きくなっている。こ れらから地山を弾性体ないしは弾塑性体, 応力変形 条件を軸対称ないしは 3 次元とするに関わらず, 数 值解析で得られる切羽前方地山のトンネル軸方向の ひずみはこのような状態となると推定できる．図-4 において $\sigma_{r}$ は切羽面以深の部分でピークを示して おり, 切羽面以深にドーム型の応力アーチが形成さ れる ${ }^{10)}$. なお，地山のポアソン比を 0.0 とした場合 にはこのような結果とはならず，切羽面に近いほど トンネル軸方向のひずみが大きくなるので，応力ア 一チの形成にはポアソン比が梁く関与しているとい える。 


\section{3. 長尺鏡ボルトエの作用効果の検討}

切羽前方地山一の対策工として，長尺鏡ボルト工 を施工した場合に，どのような効果が期待できるか について検討する.

清水・武田 ${ }^{11)}$ は，圧縮試験の解析を通じて，ケー ブルボルトの作用効果を検討した結果，地山を弾塑 性体とした場合にはボルトの打設本数が多くなるに つれピーク強度が増加するとともに延性的な挙動と なることや，地山をひずみ軟化体とした場合にはピ 一ク強度, 残留強度が増加することを示した。ここ では同様に平面ひずみ状態で圧縮試験の解析を行い, 低強度地山における長尺鏡ボルト工（GFRP 管）の 作用効果について検討する.

前章と同様に, 地山は表-1 に示寸粘性土地山に掘 削されたトンネルの物性を用いて弾塑性体としてモ デル化する. 地山条件によって長尺鏡ボルト工の作 用効果がどのように変化するかについて調べるため, ここではヤング率 $E$ および粘着力 $C$ を 0.5 倍 $(E=5 \mathrm{MPa}, C=0.04 \mathrm{MPa}), 2.0$ 倍 $(E=20 \mathrm{MPa}$, $C=0.16 \mathrm{MPa}$ ）とした場合についても考慮する. GFRP 管は外径 $76 \mathrm{~mm}$, 内径 $60 \mathrm{~mm}$ のものを想定し, 既往 の研究 1), 5), 6)やカタログを参考にヤング率を $20 \mathrm{GPa}$ として棒要素でモデル化する．また，ここでは長尺 鏡ボルトと地山の付着が強い場合を想定し，これら の間に生じるす心゙りは考慮しない，長尺鏡ボルトの 打設密度は表-2 のとおりとし, 図-6に示すモデル上 端に強制変位を与え，軸ひずみが $3 \%$ となるまで圧 縮を行う. 表-1の地山に掘削された内空高さが $10 \mathrm{~m}$ のトンネルにおいて, 後述するように切羽前方地山 に長尺鏡ボルトを打設し, 地中沈下計で切羽到達前 から切羽到達後までの天端沈下量を計測したところ， 約 $150 \mathrm{~mm}$ であった. よって内空変位量をその 2 倍 の $300 \mathrm{~mm}$ 程度と考えると, 切羽前方地山のひずみ 量は最大でも $3 \%$ 程度であったと考えられる. 切羽 前方地山のひずみ量は, 地山条件や長尺鏡ボルトの 打設密度により異なると考えられるが，本トンネル の計測結果を参考に, 解析においては軸ひずみを $3 \%$ までとした，想定している地山物性では，拘束圧が 作用しない場合には，軸ひずみが $2 \%$ となった時点 で地山が塑性化することになるので, 塑性化が発生 しない軸ひずみが $1 \%$ の時点と, 塑性化が発生する 軸ひずみが $3 \%$ の時点について結果を整理する.

得られた結果を $E^{\prime} / E$ と打設密度の関係として描 いたものが図-7である.ここで $E ’$ は地山の軸応力と 軸ひずみから求まる割線ヤング率であり, $E^{\prime} / E$ が 1.0 より小さな場合には地山が局所的あるいは全体的に 塑性化していることになる. 表-2＼cjkstart長尺鏡ボルトの打設密度

\begin{tabular}{|c|c|}
\hline $\begin{array}{c}\text { 打設本数 } \\
(\text { 本 })\end{array}$ & $\begin{array}{c}\text { 打設密度 } \\
\left(\text { (本 } / \mathrm{m}^{2}\right)\end{array}$ \\
\hline 0 & 0.0 \\
\hline 1 & 0.1 \\
\hline 3 & 0.3 \\
\hline 5 & 0.5 \\
\hline 9 & 0.9 \\
\hline
\end{tabular}

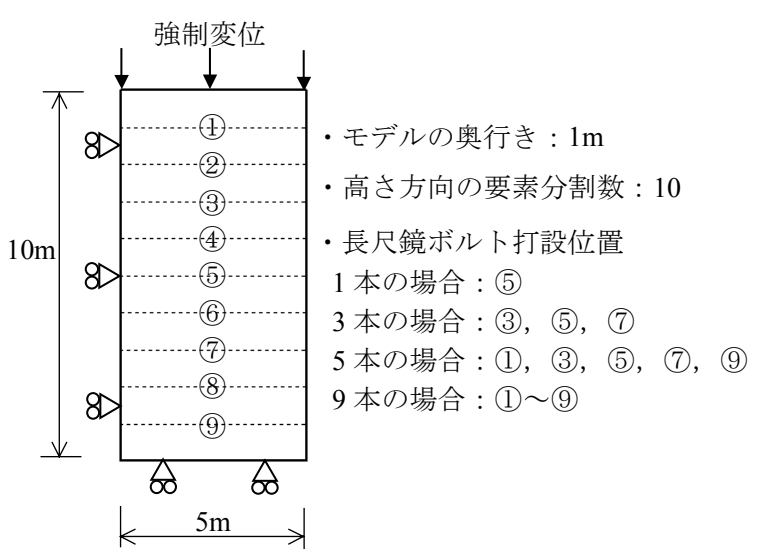

図-6＼cjkstart圧縮試験モデル

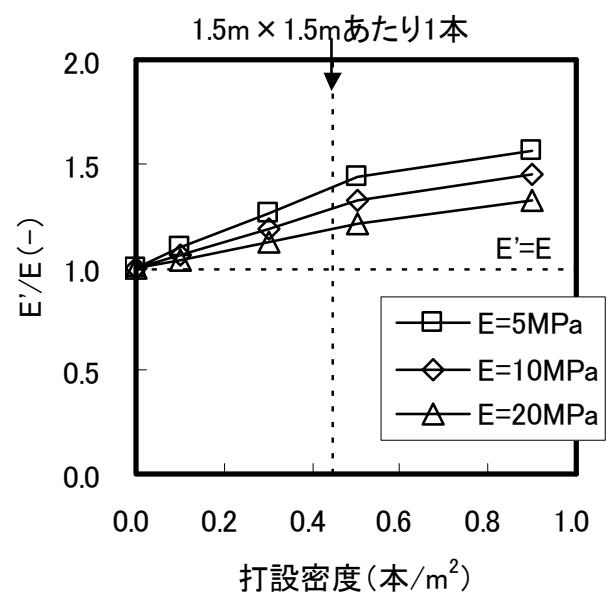

(a) 軸ひずみ $1 \%$

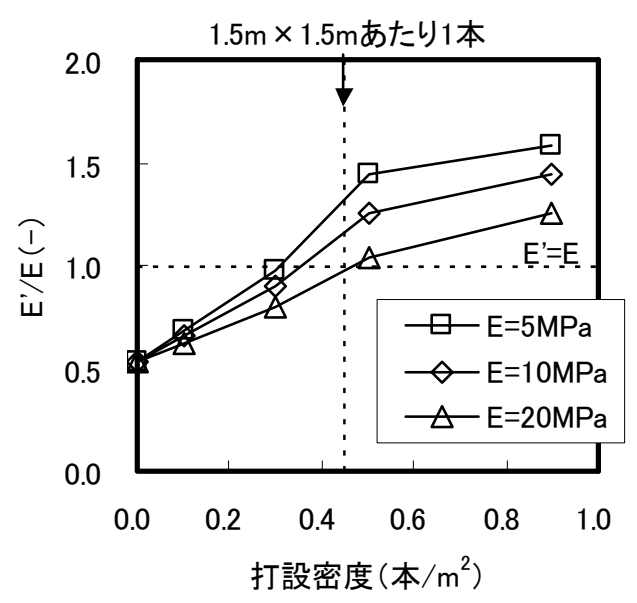

(b) 軸ひずみ $3 \%$

図-7 $\quad E^{\prime} / E$ と打設密度の関係 
長尺鏡ボルトの打設密度が大きくなるに従い, $E^{\prime} / E$ が大きくなる. 打設密度が小さな場合には, 軸 ひずみの増加に伴い地山が塑性化し, $E^{\prime} / E$ が減少す る傾向を示すが, 打設密度が大きな場合には $E^{\prime} / E$ の 減少は小さい. また地山強度が小さいほど $E^{\prime} / E$ が大 きく, 長尺鏡ボルトによる補強効果が高い。これら は長尺鏡ボルトの打設により, 地山のボルト軸方向 の変形が拘束されて, 地山の耐荷能力が増加するた めであり, 土屋 ${ }^{8)}$ がロックボルトの地山補強効果に ついて模型実験で得た結果と同様である.ただし地 山物性によらず, 打設密度が 0.5 本 $/ \mathrm{m}^{2}$ より大きくな れば, それ以上に打設密度を大きくしても $E^{\prime} / E$ の増

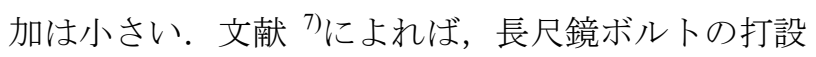
間隔を $1.5 \mathrm{~m} \times 1.5 \mathrm{~m}$ に 1 本とした施工事例が多く報 告されている，その場合の打設密度を図にあわせて 示すが，長尺鏡ボルト工による十分な効果が期待で きる打設密度の目安となっていると考えられる。

これまで示した結果は長尺鏡ボルトと地山の付着 力が大きく, 両者間のすべりが生じない場合である. しかしながら, Hyatte ら ${ }^{12}$ はケーブルボルトの引抜 き試験を行い，ボルトの効果がボルトとグラウトの 付着特性に依存するとした。 また, 尾原ら ${ }^{13}$ はロッ クボルトとケーブルボルトを用いて室内引抜き試験 を実施した．X 線 CT 法で付着破壊の様子を可視化 して, 引抜き荷重-変位曲線や付着破壊の様子がボル トの種類や表面形状に依存するとした。大塚ら ${ }^{14)}$ は原位置において長尺鏡ボルト（GFRP 管）の引抜 き試験を 3 種のグラウト材について実施し, ボルト とグラウトの付着剛性や強度がウレタン, シリカレ ジン，モルタルの順に大きくなることを示した。 よ ってボルトと地山の付着特性は施工条件により複雑 に異なり, 原位置において引抜き試験を実施し, 付 着力を確認する必要がある.

ここでは平面ひずみ状態を想定しており，実際の 切羽前方地山の挙動とは異なる可能性がある. しか しながら適切な打設本数で長尺鏡ボルト工が施工さ れ, 十分な付着が確保される場合には, 切羽前方地 山が弾性的な挙動を示すものとして近似的に取り扱 うことができることを図-7 は示唆していると考え た.

\section{4. 簡易評価モデルの提案}

\section{（1）簡易評価モデル}

適切な打設本数で長尺鏡ボルト工が施工され，十 分な付着が確保される場合を前提として, 図-1に示 す軸対称モデルにおいて, 長尺鏡ボルト工による切

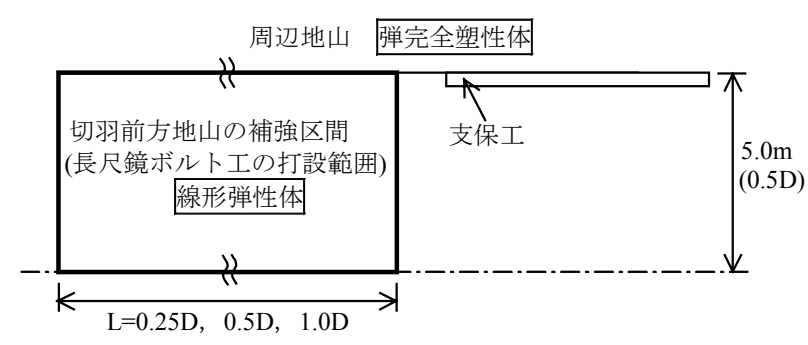

図-8 長尺鏡ボルト工による先行補強効果の 簡易評価モデル

羽前方地山の補強区間を等方弾性体として, 表-1に 示すヤング率とポアソン比を用いて解析を行う（図 -8). 補強区間長 $L$ は長尺鏡ボルトの打設長に該当 する. 切羽前方地山の補強区間を除く周辺地山は弾 塑性体として，表-1 に示寸物性值を用いる.

長尺鏡ボルト工の採用によりどの程度の効果が得 られるかを検討寸るにあたり，このような簡易なモ デルは，例えば以下のような利点を有している． 3 次元解析と比較して計算速度の向上が図れ, 様々な 条件における検討が容易に行える. 長尺鏡ボルトを 3 次元的かつ詳細にモデル化する必要がなくなる. さらに, 平面ひずみ解析とは異なり, 応力解放率を 設定せずとも切羽進行の 3 次元的効果を考慮できる.

ここでは簡易評価モデルでどのような挙動を表現 できるかについて検討した後, 長尺鏡ボルト工を採 用した現場における計測結果と比較することにより， その適用性について考察する.

\section{（2）本論文におけるモデル化}

例示的に $L$ が $0.25 D, 0.5 D$ および $1.0 D(D$ はトン ネル直径 $10.0 \mathrm{~m}$ ) の場合を考慮し, 掘削が $1.0 \mathrm{~m}$ 進行 するごとに補強区間を $1.0 \mathrm{~m}$ 延長して解析を行う。 現実には，(1)〜 (3)の手順で施工が行われるが，長尺 鏡ボルト工による効果が期待できるボルト長（ラッ プ長) を確認するために, 常に(2)の状態で施工が行 われるとして，モデル化を行った。

（1）長尺鏡ボルト工で区間 $L （ 1.0 ２ .0 D ）$ を補強 する

(2) 所定のボルト残長 (ラップ長) となるまでト ンネルを掘削する

(3) (1)と(2)を繰り返す

長尺鏡ボルト工による補強区間を現実の施工に比 べて短くモデル化しているので, 現実の施工で長尺 鏡ボルト工に期待できる効果は本解析で得られるも のより大きくなると考えられる.

\section{（3）トンネル周辺地山の応力, ひずみ状態}

切羽位置 $z$ が $50 \mathrm{~m}$ の時点（ $5 D$ 通過時）での要素 


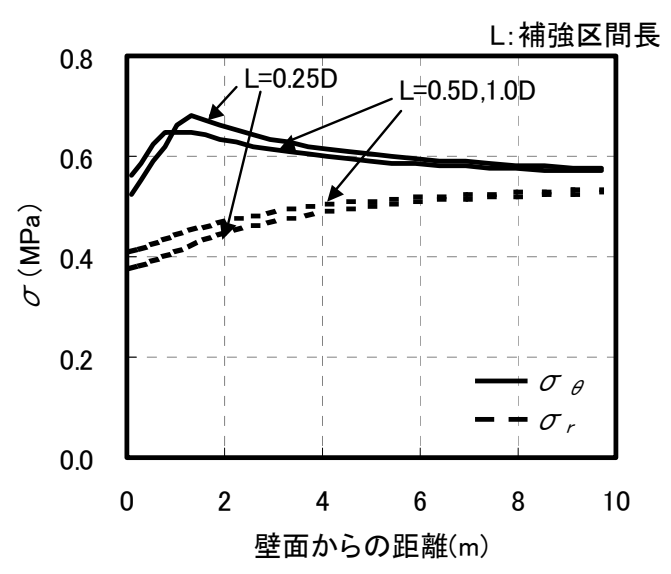

図-9 要素群 A のトンネル周方向および半径方向の応力 ( $5 D$ 通過時)

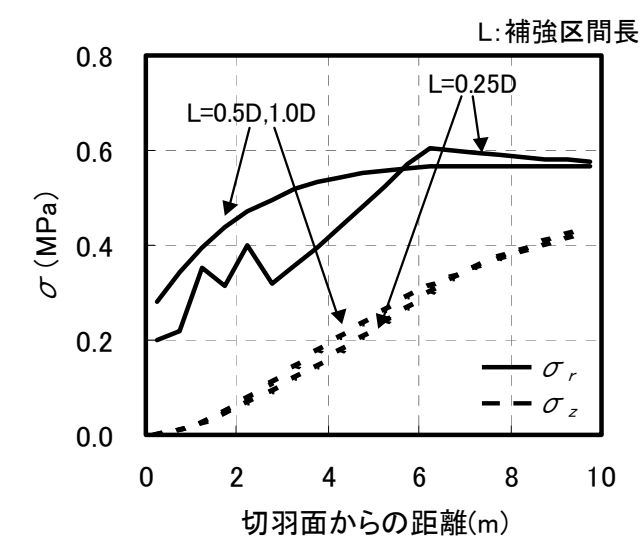

図-11 要素群 B のトンネル半径方向および軸方向の応力 (切羽到達時)

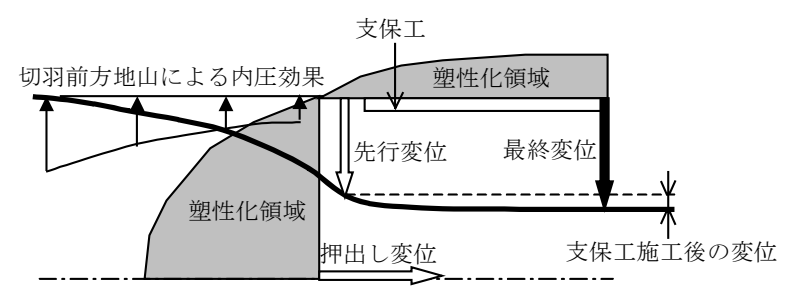

（a）長尺鏡ボルト工がない場合

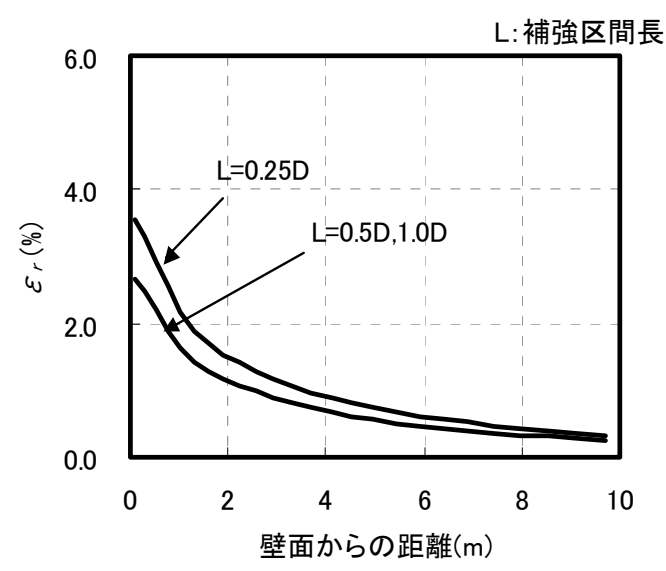

図-10 要素群 A のトンネル半径方向のひずみ ( $5 D$ 通過時)

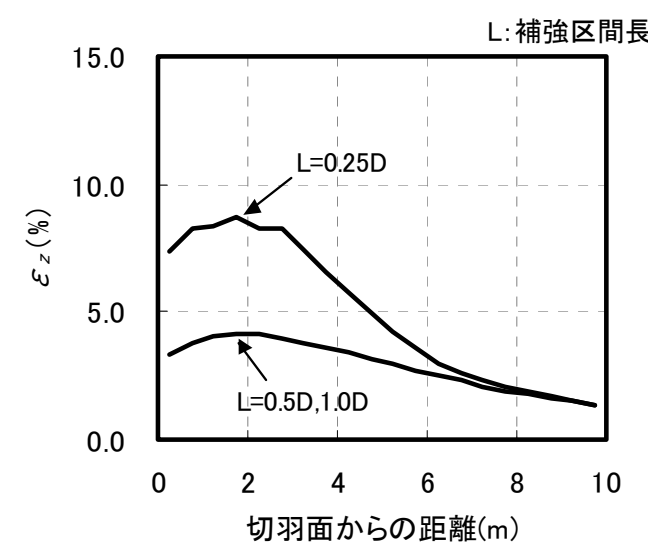

図-12 要素群 B のトンネル軸方向のひずみ (切羽到達時)

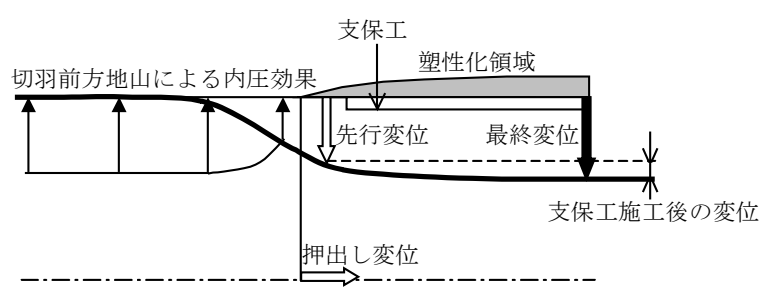

（b）長尺鏡ボルト工がある場合

図-13 押し出し性地山において切羽前方地山が発揮する内圧効果の模式図

群 A（図-1 (b)） におけるトンネル周方向応力 $\sigma_{\theta}$ お よびトンネル半径方向応力 $\sigma_{r}$ を図-9 に, トンネル 半径方向のひずみ $\varepsilon_{r}$ を図-10に示す. 図-2 および図 -3 と比較すると, 切羽前方地山の補強区間 $L$ のみを 弾性体としているにも関わらず， $L$ を $0.5 D, 1.0 D$ と して得られる結果は地山全体を弾塑性体とした場合 と比較して，弾性体とした場合に近くなっている。 また補強区間長 $L$ が $0.25 D$ の場合の結果は $0.5 D$ と $1.0 D$ の場合の結果と異なるが， $0.5 D$ と $1.0 D$ の場合 の結果は変わらない.

切羽位置 $z$ が $0 \mathrm{~m}$ の時点（切羽到達時）での要素 群 B (図-1(b)) におけるトンネル半径方向応力 $\sigma_{r}$
およびトンネル軸方向応力 $\sigma_{z}$ を図-11に，トンネル 軸方向のひずみ $\varepsilon_{z}$ を図-12 に示す. なおこれらの図 において, 切羽面近傍の值が滑らかとなっていない のは, 解析モデル (図-1 (b)) のトンネル軸方向 $1.0 \mathrm{~m}$ あたりの要素分割数を 2 としており，トンネル軸方 向 $1.0 \mathrm{~m}$ 区間内に小さな応力アーチが形成されてい るためと考えられる．補強区間長 $L$ が $0.25 D$ の場合 の切羽面近傍におけるトンネル半径方向応力 $\sigma_{r}$ は $0.5 D$ と $1.0 D$ の場合に比較し小さい. また $L$ が $0.25 D$ の場合のトンネル軸方向ひずみ $\varepsilon_{z}$ は $0.5 D$ と $1.0 D$ の 場合に比較し大きい. $L$ が $0.5 D$ と $1.0 D$ の場合の応 力やひずみの結果は同じである。 $L$ が $0.25 D$ の場合 
には切羽面からおよそ $6.0 \mathrm{~m}$ 以浅の $\sigma_{r}$ が低下してい る。これは補強範囲以深の地山が塑性化しているた めであり, その結果 $\varepsilon z$ が大きくなっている.

ここでは長尺鏡ボルト工による切羽前方地山の補 強区間長 $L$ を $0.25 D, 0.5 D$ および $1.0 D$ として, その 範囲を弾性体とした軸対称解析を行った。 切羽前方 地山の補強区間のみを弾性体としたにも関わらず, $L$ を $0.5 D, 1.0 D$ として得られる結果は地山全体を弾 性体とした場合と同様となった。 寸なわち地山強度 比が小さな押し出し性地山においては, 前述のよう に切羽前方地山の安定性がトンネルの安定性に深く 関わっている. 模式的に図-13 に示寸ように, 長尺 鏡ボルト工によりトンネル軸方向の変形が拘束され, 切羽前方地山の塑性化が抑制される結果, 切羽前方 地山が発揮する内圧効果が図 (a) から図 (b) 一と変化 するので, 先行変位や押出し変位が抑制され, トン ネルの安定性を向上させると考えられる.

\section{（4）補強区間長と変位の結果}

長尺鏡ボルトの打設長やラップ長が適切でない場 合には地山補強効果が期待できなくなることを図-9 〜図-12 は示唆している. 池口・真下 ${ }^{15)}$ は遠心載荷 により鏡ボルトの効果について詳細な実験を行った. 模型材料は砂であり本論文で想定した粘性土地山の 条件とは異なるが，ボルトによる補強区間長を $0.5 D$ 以上とした場合には切羽崩壊が抑制されるが, $0.25 D$ の場合には顕著な効果が認められなかったことを報 告した.またボルトによる補強区間長が $0.5 D$ 以上あ れば, 補強区間長を長くしても効果の向上は期待で きないことを報告した. Lunardi ${ }^{3}$ は V Vasto トンネルに おいて長尺鏡ボルトの残長が $1.5 D(D$ はトンネル直 径 $10.0 \mathrm{~m} ）$ から $0.5 D$ になるにつれ, 内空変位や押出 し変位が増加したことを報告した。

図-1 (b) に示寸節点の内空方向への変位 $u$ の最終 值（5D 通過時）と補強区間長 $L$ の関係を示したも のが図-14 である.ここで $L$ が $0.0 D$ の結果は地山全 体を弾塑性体とした場合の結果である。また図には ヤング率 $E$ および粘着力 $C$ を 0.5 倍 $(E=5 \mathrm{MPa}$, $C=0.04 \mathrm{MPa}), 2.0$ 倍 $(E=20 \mathrm{MPa}, \quad C=0.16 \mathrm{MPa})$ とし た場合の結果もあわせて示す.

補強区間長 $L$ が $0.5 D$ 以下の場合の変位量は $0.5 D$ 以上の場合に比較し大きく, 補強による効果が小さ い. また $L$ が $0.5 D$ 以上の場合には変位量に顕著な 差が生じない傾向を示寸。これらから地山条件によ り多少の差があるものの, 長尺鏡ボルト工による効 果が期待できるボルト残長（ラップ長）の目安は $0.5 D$ 程度以上であると考えられる。

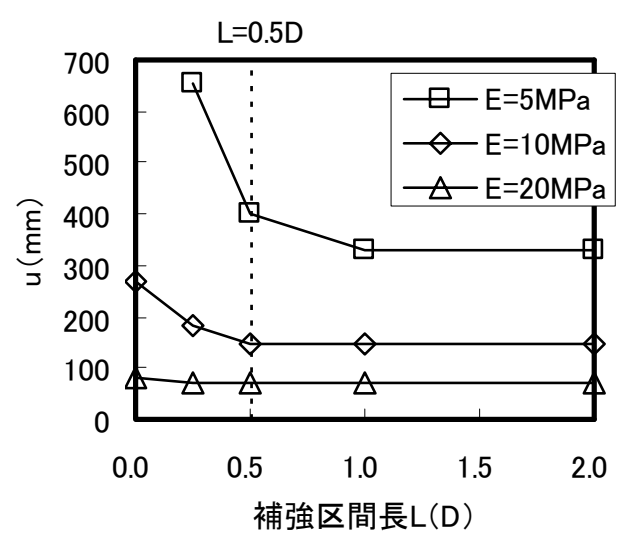

図-14 最終壁面変位量と補強区間長の関係

\section{（5）現場計測結果との比較}

長尺鏡ボルト工を採用した現場における計測結果 と比較することにより，簡易評価モデルの適用性に ついて考察する.

\section{a） 施工概要 ${ }^{16)}$}

地質は新第 3 紀の泥岩層 ${ }^{17)}$ であり, トンネル底盤 で実施された平板載荷試験および切羽から採取され た岩石試料を用いた三軸圧縮試験により取得された 地山物性は表-1のとおりであった。

トンネルの内空高さは約 $10 \mathrm{~m}$, 土被りは最大で約 $20 \mathrm{~m}$ であった。 ミニベンチ工法が採用され，インバ 一ト支保工による速やかな断面閉合が行われた。 $0.25 \mathrm{~m}$ の吹付けコンクリートと H-200 の鋼製支保工 （設置間隔 1.0m）がインバート支保工を含む全断面 に施工された。 また切羽安定対策工として, 近傍の 類似地山における施工事例 ${ }^{18)}$ を参考に, 表-3に示す 仕様で長尺鏡ボルト工が施工された ${ }^{19}$.

\section{b）計測結果と解析結果の比較}

計測トンネルでは土被り $20 \mathrm{~m}$ の地点においてト ンネル直上に地中沈下計が設置され, 先行変位を含 む天端沈下量が計測された。また同地点において地 表面沈下量が計測された。 天端沈下量を地中沈下計 で計測したのは，長尺鏡ボルト工で補強された切羽 前方地山がどのようにトンネルの安定性に寄与して いるかを評価するためには, 先行変位の計測が必要 であると考えたためである.

地中沈下計による天端沈下量の計測結果とモデル による結果（前章で示した結果のうち，長尺鏡ボル ト工による補強区間長 $L$ が計測トンネルにおけるラ ップ長と同様の $0.5 D$ の場合）を比較したものが図 -15 である. 図は天端沈下量と切羽位置の関係で示 しており，地山全体を弾性体とした場合および弾塑 性体とした場合に得られた結果についても破線で示 している. 
表-3＼cjkstart計測トンネルにおける長尺鏡ボルト工の仕様

\begin{tabular}{|l|l|}
\hline 材質 & GFRP \\
\hline 外径 & $76 \mathrm{~mm}$ \\
\hline 内径 & $60 \mathrm{~mm}$ \\
\hline 打設長 & $21 \mathrm{~m}($ 約 $2.0 D)$ \\
\hline ラップ長 & $6 \mathrm{~m}($ 約 $0.5 D)$ \\
\hline 打設本数 & 21 本 \\
\hline 打設ピッチ & $1.5 \mathrm{~m}\left(\right.$ 約 0.5 本 $\left./ \mathrm{m}^{2}\right)$ \\
\hline 打設配置 & 同心円状 \\
\hline 注入材 & シリカレジン \\
\hline
\end{tabular}

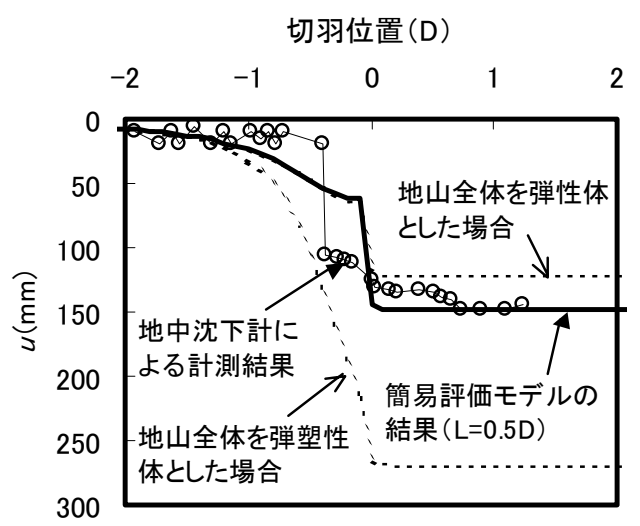

図-15 計測結果と解析結果の比較（天端沈下量）

図よりモデルによる結果は実用的な範囲で天端沈 下量の計測結果を表現できており，十分使用に耐え うることが分かる.

土被りが小さなトンネルにおいては, 地表面への 影響が問題となることが多いが，採用した軸対称モ デルでは地表面沈下量を直接的に求めることができ ない.ここではモデルで得られる天端沈下量 $u$ から 式(1)で表せる弾性理論を用いて地山の見かけのヤ ング率 $E$ 'を求める ${ }^{2)}$. 次に Limanov ${ }^{20)}$ が提案した式 (2)によって地表面沈下量 $U$ を求め, 計測結果と比較 することとする.

$$
\begin{gathered}
E^{\prime}=\frac{1+v}{u} \cdot \sigma_{0} \cdot r \\
U=\frac{\left(1-v^{2}\right) \cdot \sigma_{0}}{E^{\prime}} \times \frac{4 \cdot r^{2} \cdot Z}{Z^{2}-r^{2}}
\end{gathered}
$$$$
こ こ に
$$$$
E^{\prime} \quad \text { ：地山の見かけのヤング率 }
$$$$
v \quad \text { : 地山のポアソン比 }(=0.4)
$$$$
u \text { : 簡易評価モデルで得られる天端沈下量 }
$$$$
\sigma_{0}: \text { 初期応力 }(=0.55 \mathrm{MPa})
$$$$
r \quad \text { : トンネル掘削半径 }(=5.0 \mathrm{~m})
$$$$
U \text { : 地表面沈下量 }
$$$$
Z \text { : 地表からトンネル中心までの距離 }
$$$$
(=25.0 \mathrm{~m})
$$

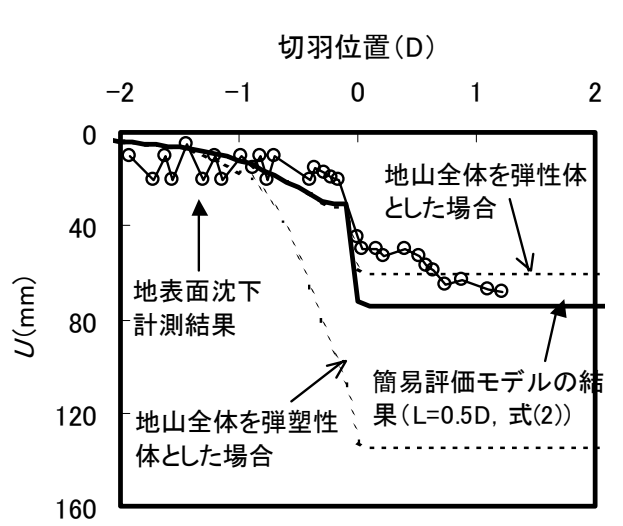

図-16 計測結果と解析結果の比較（地表面沈下量）

地表面沈下量 $U$ について計測結果と式(2)を用い て得られた結果を比較したものが図-16 である. 図 よりモデルで得られる天端沈下量から地表面沈下量 を求めた結果は実用的な範囲で計測結果を表現でき ており，このような方法で地表面沈下量の予測を行 えることが分かる.

桜井 ${ }^{2)}$ は計測変位から式(1)を用いて求まる地山の 見かけのヤング率 $E$ 'を事前調查で得られたヤング 率 $E$ で除した值 $\left(=E^{\prime} / E\right)$ を切羽安定対策工による 効果率と定義した. 計測トンネルにおける天端沈下 量から式(1)を用いて求まる効果率はおよそ 2.6 であ り, 長尺鏡ボルト工がトンネルの安定化や地表面沈 下の抑制に寄与していたものと考えられる.

これまで示したように長尺鏡ボルト工による地山 補強効果の程度は地山条件により異なると考えられ る. またボルトの材質や打設密度, ボルトと地山の 付着特性や打設長に依存することが考えられる。こ れらについて現場状況に応じて詳細な検討を行う場 合には 3 次元解析が必要となるが, 簡易評価モデル により長尺鏡ボルト工の効果や必要補強区間長につ いて事前に目安を得ることができ, 解析の大幅な効 率化を図ることができる.

\section{5. おわりに}

本論文では地山強度比が小さな押し出し性地山に おいて, 切羽前方地山の安定性がトンネルの安定性 に深く関与していることを軸対称 FEM により解析 的に示した.このような地山においては長尺鏡ボル ト工を採用することにより切羽前方地山のトンネル 軸方向の変形が拘束され, 耐荷能力が増寸結果, 卜 ンネルの安定性が向上するものと考えた。 そのよう な挙動を軸対称 FEM において切羽前方地山を弾性 体とすることにより表現することにし，これを長尺 
鏡ボルト工による効果を定量に評価するための簡易 モデルとして提案するとともに, 計算結果と現場計 測結果とを比較してその実用性を明らかにした。さ らに本検討を通じて, 地山条件により多少の差があ ると考えられるが，長尺鏡ボルト工による効果が期 待できる打設密度として $1.5 \mathrm{~m} \times 1.5 \mathrm{~m}$ あたり 1 本, ボルト残長 (ラップ長) として $0.5 D$ が一つの目安と なることを示した。

軸対称 FEM を用いており， 円形トンネルが全断 面工法で掘削され，掘削後直ちに断面の閉合が行わ れる場合を想定している。しかしながら実施工にお いては, 岩盤の時間依存性挙動, 支保工のなじみや 閉合時期などの影響で, 支保工施工後にも内空変位 が計測されることが多い。よって，これらの影響を 考慮していない本モデルを情報化施工へ活用するに は一定の限界があるので, 今後このような点につい ても検討を加えたい，また本論文で得られた長尺鏡 ボルト工による効果が期待できる打設密度やボルト 残長が, 地山条件によりどのように変化するかにつ いても検討を加えたい.

押し出し性地山においては, 剛な支保工による早 期閉合で変位抑制を行う，あるいは多重支保工法の ように状況に応じて変位抑制を段階的に行うといっ た施工法の選択も課題となっている. 今後はこのよ うな点も踏まえ, 押し出し性地山における合理的な 施工法について検討したいと考えている.

謝辞 : 本研究にあたり, 今田徹・東京都立大学名誉 教授, 西村和夫・首都大学東京教授をはじめとする 皆様から, 終始貴重な御指導を頂きました。心から 謝意を表します。

\section{参考文献}

1)西崎晶士, 羽馬徹, 岡部正 : 長尺鏡ボルトの施工動向と 挙動特性の解析的研究, トンネル工学研究論文・報告 集, 第 12 巻, pp.131-136, 2002.

2)桜井春輔 : 都市トンネルの実際 合理的な設計・施工法 をめざして, 鹿島出版会, 1998.

3)Lunardi, P. : The design and construction of tunnels using the approach based on the analysis of controlled deformation in rocks and soils, Tunnels and Tunnelling international, pp.3-30, 2000.

4)吉岡尚也, 木梨秀雄, 道廣一利, 谷本親伯 : 鏡止めボル トによるトンネル切羽面の補強効果, 土木学会論文集, No.638／III-49, pp.389-394, 1999.

5)清水利朗, 尾畑洋, 松尾勉, 手塚仁, 岡部正 : 長尺切羽 補強工を施工した切羽前方地山の挙動について, トン ネル工学研究論文・報告集, 第 13 巻, pp.225-230, 2003.
6)宮野前俊一, 森田篤, 松井幹雄, 酒井照夫, 梨本裕 : 未 固結地山における切羽安定対策工の効果に関する一考 察, トンネル工学報告集, 第 14 巻, pp.107-114, 2004. 7)ジェオフロンテ研究会 : ケーブルボルトに関する調査報 告書, 長尺鏡ボルトの施工実態調查結果とその分析, 1998.

8)土屋敬 : ロックボルト・吹付けコンクリート工法の設計 に関する研究, 京都大学学位論文, 1986.

9)北里新生, 飯村博之, 梨本裕, 椙山孝司 : 3 次元弾塑性 FEM 解析による長尺鏡ボルトの支保効果に関する検討, トンネル工学研究論文・報告集, 第 5 巻, pp.303-308, 1995.

10)今田徹, 山崎良一: 曲面切羽に関する研究, 土木学会 第 51 回年次学術講演会講演概要集, III-B55, pp.110-111, 1996.

11)清水則一, 武田智治 : 軟岩に対するケーブルボルトの 適用性について, トンネル工学研究論文・報告集, 第 7 巻, pp.111-116, 1997.

12)Hyatte, A.J., Bawden, W.F. and Reichert, R.D. : The effect of rock mass confinement on the bond strength of fully grouted cable bolts, Int. J. Rock Mech. Min. Sci. \& Geomech. Abst., Vol.29, No.5, pp.503-524, 1992.

13)尾原祐三, 前野保一, 川野龍一, 伊藤文雄, 中原史晴 : 引張試験におけるボルトの付着破壊, 土木学会論文集,

No.708／III-59, pp.97-106, 2002.

14)大塚勇, 青木智幸, 谷卓也, 竹津英二, 小杉勝之 : 膨 張性地山における長尺鏡ボルトの切羽補強効果の検討, トンネル工学報告集, 第 14 巻, pp.23-30, 2004.

15)池口正晃, 真下英人 : 切羽安定化のための鏡ボルトの 効果, トンネル工学研究論文・報告集, 第 7 巻, pp.93-98, 1997.

16)佐藤映, 松長剛, 小島正人, 酒井照夫 : 市街地地す心゙ り地帯のめがねトンネル, トンネルと地下, 第 34 巻, 8 号, pp.21-29, 2003.

17)市橋清功, 酒井照夫, 水野敏実, 安藤伸: 葉山層群衣 笠泥岩の物性に関する考察, 土木学会第 56 回年次学術 講演会講演概要集, pp.560-561， 2001.

18)根本克彦, 田井道夫, 小松敏彦, 椙山孝司: 強破砕質 泥岩の地すべり地帯を小土被りで貫く, トンネルと地 下，第 30 巻， 7 号，pp.17-26, 1999.

19)高村栄二, 佐藤映, 小島正人, 酒井照夫 : トンネル掘 削に伴う切羽前方地山挙動についての一考察 長尺鏡 ボルトの効果の検証, 土木学会第 57 回年次学術講演会 講演概要集, pp.503-504, 2002.

20)K.チェッキー著, 島田隆夫訳 : トンネル工学, 鹿島出 版会, 1971. 


\section{A PROPOSAL OF THE SIMPLIFIED MODEL TO EVALUATE THE EFFECT OF LONG FACE BOLTING}

\section{Shunichi MIYANOMAE, Atsushi MORITA, Teruo SAKAI, Mikio MATSUI, Yutaka NASHIMOTO and Seisuke OKUBO}

The stability of advanced ground core is essential to excavate the tunnel by NATM safely and stably. Therefore, long face bolting has been widely used to reinforce and support the advanced ground core especially in soft rock. In this study, a simple axi-symmetric FEM model was developed to evaluate the effect of the face bolting quantitatively. The calculated results such as tunnel convergence and surface subsidence were compared with the results of in-situ measurement. It was found that the calculated results reasonably coincided with the measured results indicating an enough potential and effectiveness of the proposed model. 